\title{
PENYUSUTAN BERAT, KARAKTERISTIK FISIK DAN KIMIA BIJI KOPI RAKYAT DI LERENG PEGUNUNGAN ANJASMORO WILAYAH KABUPATEN MOJOKERTO JAWA TIMUR
}

\author{
Eko Sutrisno $^{(1)}$ dan Nur Habibatul Sholichah ${ }^{(1)}$ \\ ${ }^{(1)}$ Prodi Teknologi Hasil Pertanian Universitas Islam Majapahit
}

ekosudrun@yahoo.com

\begin{abstract}
Abstrak
Masyarakat yang tinggal di Lereng Pegunungan Anjasmoro wilayah Kabupaten Mojokerto mulai banyak yang menanam kopi. Belum ada data jenis kopi dan kualitas atau mutu kopi yang ditanam oleh masyarakat menarik untuk dilakukan penelitian. Metode yang digunakan dalam penelitian ini yaitu deskripstif dengan survey sampling, meneliti karakteristik susut bobot, fisik dan kimiawi biji kopi (coffee bean) yang dihasilkan perkebunan kopi rakyat di lereng Pegunungan Anjasmoro wilayah Kabupaten Mojokerto. Karakter fisik meliputi diameter geometric, sphericity, luas permukaan dan volume. Karakter kimia meliputi $\mathrm{pH}$, kadar air, dan total asam. Varietas kopi di lokasi penelitian ada tiga jenis, yaitu Robusta, Exelsa dan Robusta stek dengan exelsa. Susut Berat/bobot buah kopi selama penjemuran sebesar 42,16\%, saat kulitnya dipecah susut sebesar $46,84 \%$ dan saat proses penyangraian susut sebesar 45,79\%. Diameter geometric jenis Robusta $13,80 \mathrm{~cm}^{3}$ dan jenis exelsa 11,75 $\mathrm{cm}^{3}$. Sperisitas biji kopi jenis robusta rata-rata 218,94 sedangkan jenis Exelsa 192,48. Luas permukaan kopi jenis Robusta rata-rata $16,04 \mathrm{~cm}^{2}$ dan jenis Exelsa $12,85 \mathrm{~cm}^{2}$. Volume rata-rata kopi jenis Robusta $0,021 \mathrm{~cm}^{3}$ dan kopi jenis Exelsa $0,016 \mathrm{~cm}^{3} \cdot \mathrm{pH}$ rata-rata kopi jenis Robusta sebesar 6,79 dan jenis Exelsa sebesar 6,57. Total Asam rata-rata total asam jenis Robusta sebesar 0,15\% sedangkan Exelsa 0,11\%. Kadar air kopi jenis Robusta sebesar 10,63\% dan Exelsa sebesar 11,56\%.
\end{abstract}

Kata Kunci : Susut Bobot, Kopi, Pegunungan Anjasmoro

\section{PENDAHULUAN}

Masyarakat di wilayah lereng Pegunungan Anjarmoro mulai banyak yang menanam kopi jenis Robusta, Exelsa dan stek antara Robusta dan Exelsa. Hasil wawancara dengan petani kopi saat pengambilan sampel, diketahui bahwa pengetahuan tentang budidaya dan pengolahan pasca panen kopi masih sangat sedikit. Ketika buah kopi di pohon sudah ada yang merah, maka kopi akan dipetik semua (baik yang berwarna merah atau belum) kemudian di jemur, setelah kering di jual ke tengkulak atau di sangrai sendiri untuk kebutuhan sehari-hari keluarga Petani. Proses pengolahan kopi di mulai saat panen buah masak, sortasi, pengupasan kulit buah hingga proses penyangraian (Balaya, 2013). 
Bobot kopi dari proses pemetikan hingga penyangraian banyak mengalami penyusutan. Penyusutan bobot paling besar karena proses pemanasan dan penyangraian (Mulato, 2019) dan menjadi bubuk sebesar $45 \%$ (Sucanti, 2015). Pengeringan buah kopi dengan memanfaatkan cahaya matahari memiliki banyak kelemahan, antara lain waktu pengeringan lama, kurang higienis dan membutuhkan tempat yang luas (Singh, 2015). Menurut Widyotomo (2015), jika pengeringan buah menggunakan alat, maka harus dijaga kestabilan temperatur atau suhunya, jika suhu terlalu tinggi akan merusak kualitas kopi.

Penelitian ini bertujuan untuk mengetahui susut berat/bobot saat proses pengolahan, karakter fisik dan kimia biji kopi. Hasil penelitian ini diharapkan dapat dijadikan dasar penelitian selanjutnya.

\section{METODOLOGI PENELITIAN}

Kopi untuk bahan penelitian berasal dari hasil perkebunan rakyat yang berada di desa-desa di Lereng Pegunungan Anjasmoro wilayah Kabupaten Mojokerto Jawa Timur. Sampel didapatkan dengan memanen langsung dari pohon dengan memilih buah kopi yang berwarna merah dari lahan petani yang memiliki kebun kopi paling banyak di desa tersebut. Untuk mengetahui karakteristik fisik kopi, alat yang digunakan adalah penggaris jangka sorong, pulper dan Huller adalah alat untuk mengupas kulit kopi, termometer, kompor listrik, oven, autoklaf, neraca analitik, mortar, blender, ayakan dengan lubang ukuran $7 \mathrm{~mm}$ dan $5 \mathrm{~mm}$ untuk penentuan ukuran biji kopi termasuk ukuran besar, sedang dan kecil, ayakan 60 mesh merk ABM buatan CV. Alkestrin Bagusjaya Mandiri, hotplate buatan CV. Andalan Prima Sejahtera, pH-meter buatan PT. Visco Prima Indonesia, eksikator, alat-alat gelas.

Karakter Fisika yang amati, meliputi:

1. Diameter Geometric (GM)

$$
\mathrm{GM}(\mathrm{m})=\sqrt[3]{L W T}
$$

Dimana: $\mathrm{L}=$ Length $\mathrm{W}=$ Widht

$\mathrm{T}=$ Thicknes

2. Sphericity $\left(\mathrm{S}_{\mathrm{ph}}\right)$

$$
\mathrm{S}_{\mathrm{ph}}=\left(\frac{G M}{L}\right) \times 100
$$

3. Luas Permukaan (McCabe, 1986), (Jain, 1997).

$$
S=\pi \times \mathrm{D}_{\mathrm{GM}}{ }^{2}
$$

4. Volume (Mohsenin, 1978)

$$
\mathrm{V}=\frac{\pi \times \mathrm{P} \times \mathrm{L} \times \mathrm{T}}{3}
$$

Karakter Kimia kopi yang diamati, antara lain:

1. Analisis Total Asam Tertitrasi Metode Acidi-Alkalimetri (Fardiaz, 1992). Tahapan analisis dapat dilihat pada Gambar 1.

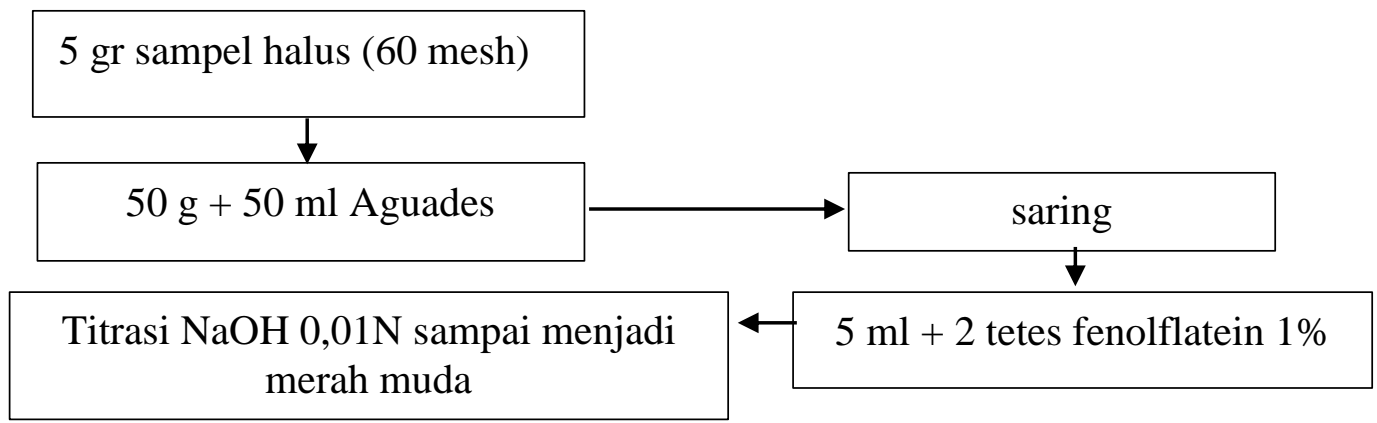

Gambar 1. Tahapan Analisis Total Asam Tertitrasi 
Rumus yang digunakan adalah :

$$
\mathrm{TAT}=\frac{\mathrm{ml} \mathrm{NaOH} \times \mathrm{N} \mathrm{NaOH} \times \mathrm{BM} \text { asam laktat } \times \mathrm{FP}}{\text { gram sampel } \times 1000} \times 100 \%
$$

2. Pengukuran $\mathrm{pH}(\mathrm{AOAC}, 2016)$

Sampel bubuk kopi diayak menggunakan ayakan ukuran 60 mesh, hingga sebanyak $5 \mathrm{~g}$ dimasukkan dalam gelas Erlenmeyer lalu ditambahkan $50 \mathrm{ml}$ aquades, kemudian diaduk hingga homogen. Pengukuran $\mathrm{pH}$ menggunakan alat $\mathrm{pH}$-meter yang dicelupkan ke dalam larutan yang telah di buat sebelumnya.

Sebelum digunakan alat $\mathrm{pH}$-meter dikalibrasi terlebih dahulu dengan buffer $\mathrm{pH} 7$ dan buffer $\mathrm{pH} 4$. (Kismurtono, 2012).

3. Kadar Air Metode Thermogravimetri (Strip, 2013)

Pengukuran kadar air sampel kopi dilakukan dengan pengeringan botol timbang kosong dalam oven bersuhu $100-105^{\circ} \mathrm{C}$ selama 30 menit didinginkan dalam eksikator 15 menit kemudian dilakukan penimbangan (a g). Sampel yang akan diukur kadar airnya dihaluskan dan diayak menggunakan ayakan 60 mesh. Sampel halus ditimbang seberat $2 \mathrm{~g}$ dan dimasukkan ke dalam botol timbang kosong yang telah dikeringkan (b g). Botol timbang yang berisi sampel dimasukkan ke dalam oven yang bersuhu $100-105^{\circ} \mathrm{C}$ selama 24 jam kemudian didinginkan dalam eksikator $( \pm 15$ menit $)$ dan ditimbang (c g). Penimbangan sampel dilakukan hingga berat konstan (selisih 0,0002 gram). Kadar air ditentukan dengan menggunakan rumus

$$
\text { Kadar air }(\mathrm{wb}) \quad=\frac{(b-c)}{(b-a)} \times 100 \%
$$

Ket:

a : Berat botol

b : Berat botol+sampel sebelum dioven

c : Berat botol+sampel setelah dioven

\section{HASIL DAN PEMBAHASAN}

Wilayah Kecamatan Gondang dan Jatirejo berada di ketinggian antara 500$600 \mathrm{mdpl}$. Hasil penelitian menunjukkan bahwa tanaman kopi yang dibudidayakan oleh warga terdiri dari tiga jenis, yaitu Robusta, Exelsa dan Rebusta hasil stek dengan Exelsa (wawancara dengan petani dan pimpinan UMKM "Nusantara Crypto Coffee") Jenis kopi di wilayah penelitian dapat dilihat pada Gambar 2, sedangkan sebaran petani kopi di Lereng Pegunungan Anjasmoro wilayah Kabupaten Mojokerto dapat dilihat pada Gambar 3. 


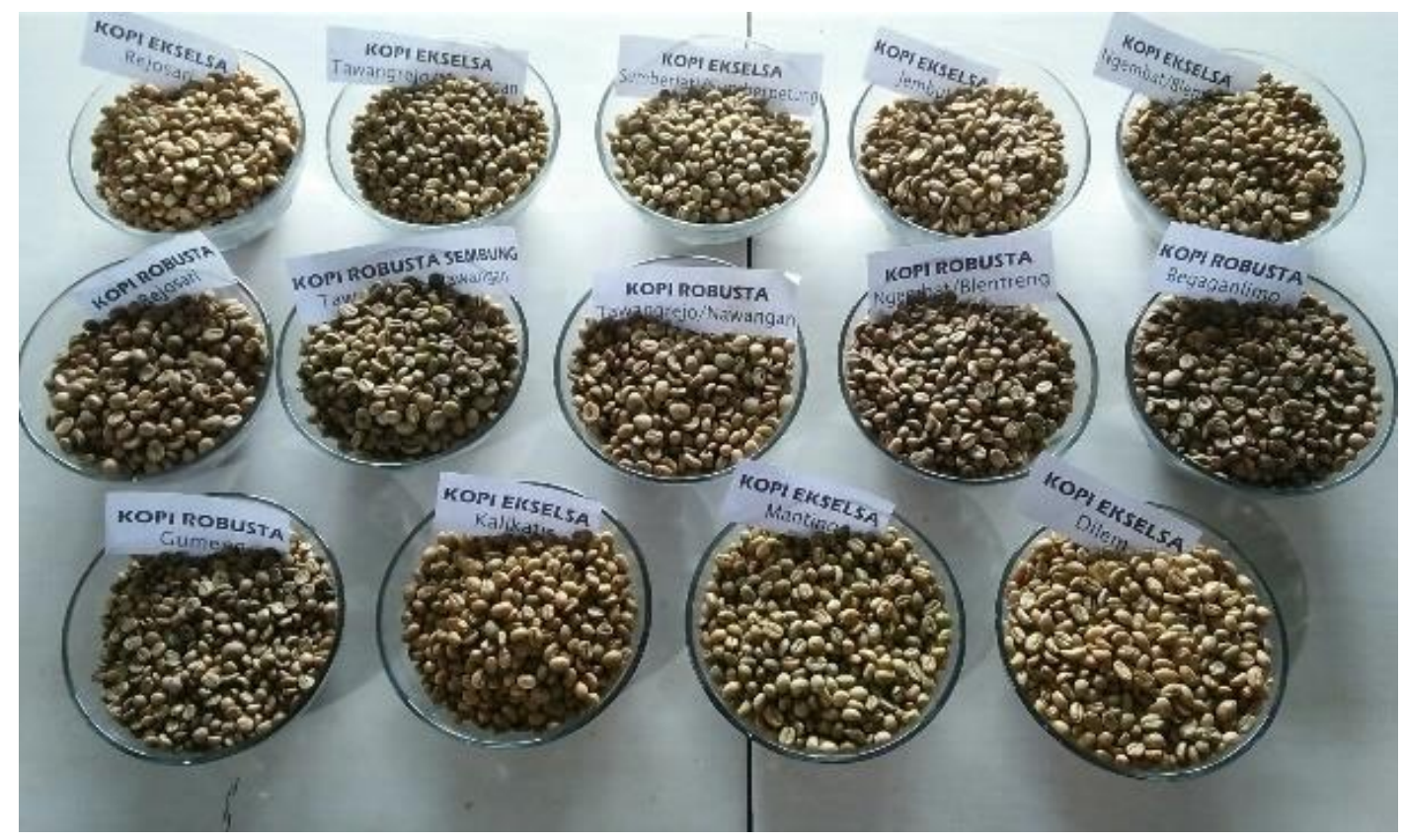

Gambar 2. Jenis Kopi di Wilayah Penelitian

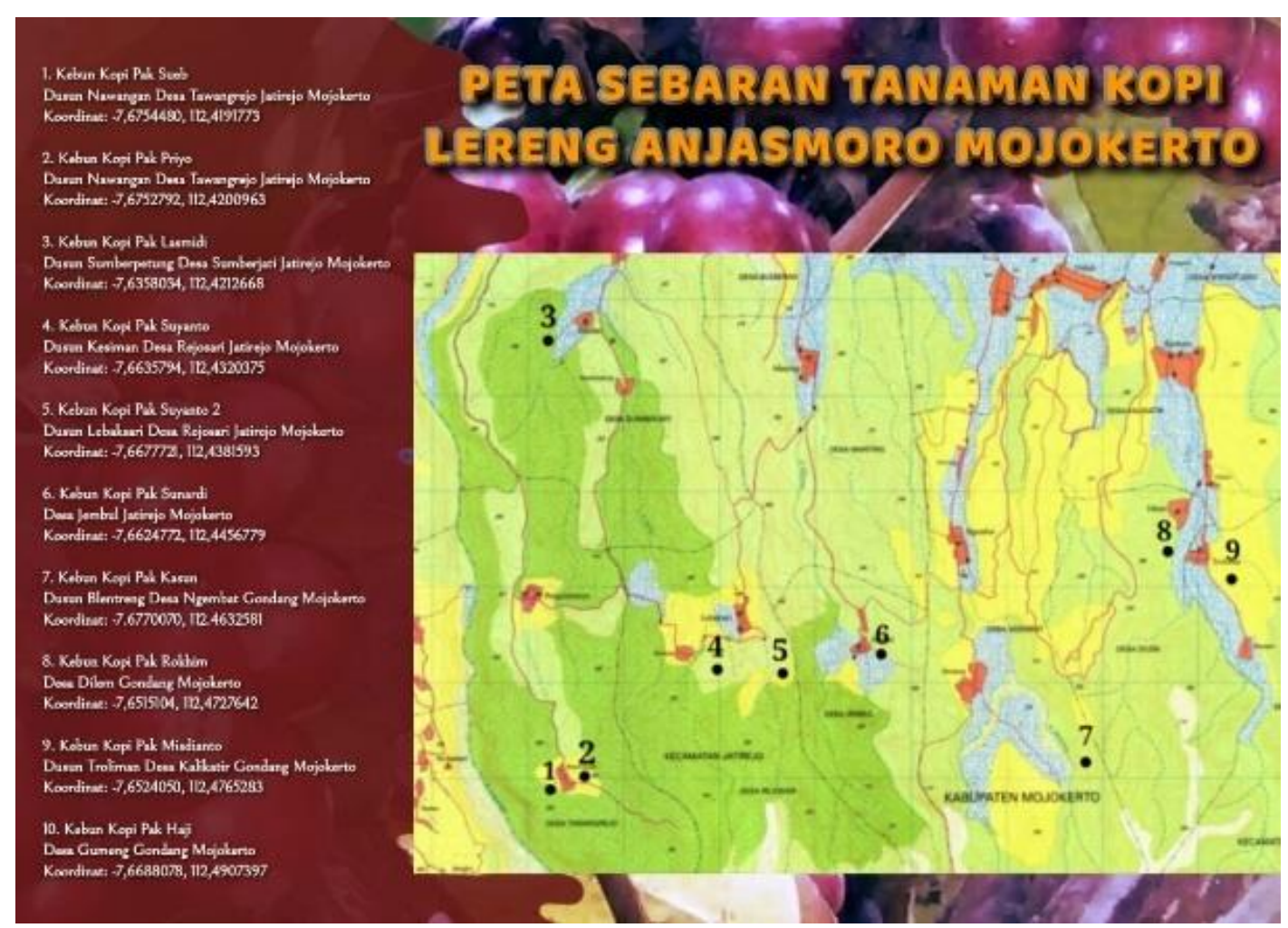

Gambar 3. Sebaran Petani Kopi di Lereng Pegunungan Anjasmoro Wilayah Kabupaten Mojokerto

Sampel buah kopi segar berwarna matahari selama 13 hari. Suhu ratamerah diambil 2000 gram di tiap lokasi, rata pada bulan agustus 2020 antara 31 kemudian dijemur dibawah sinar $34{ }^{\circ} \mathrm{C}$ kelembaban udara rata-rata $24,4^{\circ} \mathrm{C}$ 
(www.weather.com, 2020) standar deviasi 0,57 dan Relative Humidity 47\%. Menurut Widyotomo (2015), pengeringan kopi sebaiknya pada suhu $50-55^{\circ} \mathrm{C}$, agar perpindahan air didalam biji kopi berjalan dengan baik. Penyusutan bobot buah kopi setelah dipetik dan dijemur selama 13 hari mengalami susut rata-rata $1.156,86 \mathrm{~g}(42,16 \%)$. Ketika kulitnya di pecah, mengalami penyusutan berat sebesar 450,88 g (46,84\%). Penyangraian menggunakan oven berat turun rata-rata 215,04 g (45,79\%). Sementara Lia (2017), menyatakan bahwa penjemuran di bawah matahari memerlukan waktu 25 hari untuk mencapai kadar air 12\% dan secara berturut-turut mengalami penyusutan berat/bobot sebesar $75 \%$ untuk menjadi buah kopi kering dan kembali menyusut sebesar $40 \%$ saat kulitnya di pecah (green bean). Pada proses grading berat biji kopi menyusut sebesar $15 \%$ karena adanya biji kopi yang cacat fisik seperti biji kopi berlubang, pecah, dan warnanya hitam.

Penyusutan berat kopi dipengaruhi oleh keberadaan air di dalam biji kopi. Kadar air bubuk kopi yang dihasilkan rata-rata sebesar $11,43 \%$, sesuai standar SNI (BSN, 2004). Semakin lama waktu penyangraian, kadar airnya semakin rendah (Purnamayanti, 2017; Fisdiana, 2018). Guna mengetahui proporsi ukuran biji kopi (coffee bean) dilakukan proses pengayangan dengan ukuran $7 \mathrm{~mm}$ dan 5 $\mathrm{mm}$, hasilnya sebagaimana terlihat pada Tabel 1.

Tabel 1. Mutu Biji Kopi Setelah Pengayaan

\begin{tabular}{cccc}
\hline \multirow{2}{*}{ Kode } & \multicolumn{3}{c}{ Persentase Ukuran Biji $(\%)$} \\
\cline { 2 - 4 } & Besar & Sedang & Kecil \\
\hline BLR & 28.4 & 32.0 & 39.6 \\
NGE & 26.6 & 28.1 & 45.3 \\
JBE & 30.3 & 31.9 & 37.8 \\
RSR & 34.9 & 40.1 & 25.0 \\
RSE & 37.4 & 40.2 & 22.5 \\
SJE & 36.7 & 39.4 & 23.9 \\
KKE & 28.0 & 41.5 & 30.5 \\
TRR & 25.2 & 37.2 & 37.7 \\
TRE & 0.0 & 42.7 & 57.3 \\
TRS & 22.4 & 28.6 & 49.0 \\
GME & 26.4 & 18.3 & 55.3 \\
MTE & 39.6 & 34.5 & 25.9 \\
NGR & 42.2 & 38.2 & 19.6 \\
DLE & 35.3 & 46.1 & 18.7 \\
\hline Rata-Rata & $\mathbf{2 9 . 5}$ & $\mathbf{3 5 . 6}$ & $\mathbf{3 4 . 9}$ \\
\hline
\end{tabular}

Berdasarkan SNI 01-2907-2008 mutu ukuran biji kopi ada tiga kategori yaitu, ukuran besar, sedang, dan ukuran kecil. Biji kopi dikelompokkan ke dalam ukuran besar jika biji tidak lolos ayakan berdiameter $7 \mathrm{~mm}$. Biji kopi yang lolos pada proses pengayakan dengan ukuran $5 \mathrm{~mm}$ dimasukkan katagori kopi berukuran kecil. Biji kopi yang tidak lolos ayakan ukuran $5 \mathrm{~mm}$ dan yang lolos ayakan ukuran $7 \mathrm{~mm}$, masuk katagori ukuran sedang. Kopi di lokasi penelitian terdapat 3 jenis, yaitu jenis Robusta, Exelsa dan hasil stek/sembung antara Robusta dan Exelsa. Secara umum fisik kopi jenis Robusta 
volumenya lebih besar daripada Exelsa. Berdasarkan Tabel 1 diketahui bahwa mutu kopi di wilayah penelitian sebesar $35,6 \%$ termasuk dalam katagori sedang dengan bentuk biji kopi terlihat utuh dan cenderung bulat.

\section{Karakter Fisik Biji Kopi}

Karakter fisik biji kopi yang diukur pada penelitian ini adalah pengukuran diameter geometric (GM), sphericity $\left(\mathrm{S}_{\mathrm{ph}}\right)$, luas permukaan, dan volume biji kopi. Kopi hasil pengayaan, dilakukan pengukuran Diameter Geometric (GM) hingga volume permukaan biji kopi menggunakan bantuan mikrometer skrup. Ilustrasi pengukuran dapat dilihat pada Gambar 4. Karakteristik fisik biji kopi hasil pengukuran dapat dilihat pada Tabel 2 .
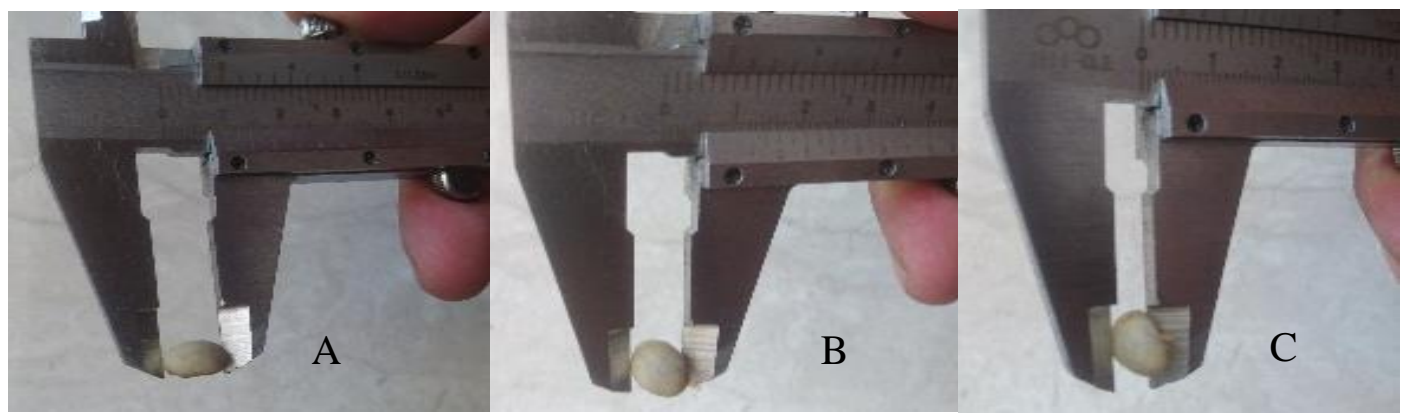

Gambar 4. Cara Mengukur Karakter Fisik Kopi, A) Panjang Biji Kopi, B) Lebar Biji Kopi dan, C) Ketebalan Biji Kopi.

Tabel 2. Karakter Fisik Biji Kopi di Lereng Pegunungan Anjasmoro Mojokerto

\begin{tabular}{|l|r|r|r|r|}
\hline Kode & \multicolumn{1}{|c|}{ GM } & \multicolumn{1}{c|}{$\mathrm{S}_{\mathrm{ph}}$} & $\mathrm{LP}\left(\mathrm{cm}^{2}\right)$ & $\mathrm{V}\left(\mathrm{cm}^{3}\right)$ \\
\hline BLR & 11.563 & 194.104 & 11.768 & 0.013 \\
\hline NGE & 9.347 & 153.428 & 9.371 & 0.010 \\
\hline JBE & 12.534 & 181.661 & 13.741 & 0.016 \\
\hline RSR & 14.428 & 224.271 & 17.030 & 0.022 \\
\hline RSE & 13.083 & 184.350 & 13.951 & 0.016 \\
\hline SJE & 10.996 & 170.966 & 11.739 & 0.014 \\
\hline KKE & 11.212 & 177.775 & 12.159 & 0.014 \\
\hline TRR & 14.767 & 233.108 & 18.336 & 0.026 \\
\hline TRE & 6.095 & 111.136 & 5.978 & 0.006 \\
\hline TRS & 13.369 & 206.710 & 15.999 & 0.021 \\
\hline GME & 16.893 & 386.701 & 21.956 & 0.032 \\
\hline MTE & 13.083 & 184.350 & 13.951 & 0.016 \\
\hline NGR & 14.428 & 224.271 & 17.030 & 0.022 \\
\hline DLE & 12.534 & 181.661 & 13.741 & 0.016 \\
\hline
\end{tabular}

Keterangan:

$\mathrm{GM}=$ Diameter geometric $\left(\mathrm{cm}^{3}\right)$

$\mathrm{S}_{\mathrm{ph}} \quad=$ Sphericity
$\mathrm{L} \quad=$ Luas Permukaan $\left(\mathrm{cm}^{2}\right)$

$\mathrm{V} \quad=$ Volume $\left(\mathrm{cm}^{3}\right)$ 
Berdasar pada Tabel 2 diketahui bahwa diameter geometric kopi jenis Robusta rata-rata lebih besar dari pada jenis exelsa, yaitu $13,80 \mathrm{~cm}^{3}$ dan 11,75 $\mathrm{cm}^{3}$. Sperisitas biji kopi jenis robusta rata-rata sebesar 218,94, sedangkan jenis Exelsa sebesar 192,48. Data tersebut menunjukkan bahwa ukuran kopi jenis Robusta di lokasi penelitian lebih besar dari pada kopi jenis Exelsa. Luas permukaan kopi jenis Robusta rata-rata sebesar 16,04 $\mathrm{cm}^{2}$ dan jenis Exelsa 12,85 $\mathrm{cm}^{2}$. Volume rata-rata kopi jenis Robusta $0,021 \mathrm{~cm}^{3}$ dan kopi jenis Exelsa $0,016 \mathrm{~cm}^{3}$. Nilai Sperisitas berbanding lurus dengan luas permukaan dan volume pada biji kopi di lokasi penelitian. Karakteristik fisik seperti panjang, lebar, ketebalan dan bentuk biji kopi merupakan salah satu kualitas yang penting bagi industri kopi (Behailu, 2008); (Giomo, 2012). Perbedaan kondisi fisik biji kopi dipengaruhi oleh jenis kopi. Kopi jenis Exelsa rata-rata memiliki volume dan luas permukaan lebih kecil daripada jenis Robusta. Kondisi tersebut juga dipengaruhi oleh proses budidaya atau perawatan tanaman (Muschler, 2001).

\section{Karakter Kimia Biji Kopi}

Karakter kimia biji kopi yang diukur pada penelitian ini adalah analisis total asam, pH, dan kadar air. Hasil pengukuran karakter kimia biji kopi dapat dilihat pada Tabel 3.

Tabel 3. Karakter Kimia Kopi di Lereng Pegunungan Anjasmoro Mojokerto

\begin{tabular}{|c|c|c|c|}
\hline Kode & $\mathrm{pH}$ & Total Asam (\%) & Kadar air (\%) \\
\hline BLR & 6.72 & 0.05 & 11.00 \\
\hline NGE & 6.31 & 0.09 & 10.50 \\
\hline JBE & 7.19 & 0.17 & 11.00 \\
\hline RSR & 7.11 & 0.27 & 10.50 \\
\hline RSE & 6.54 & 0.06 & 11.50 \\
\hline SJE & 6.48 & 0.12 & 11.00 \\
\hline KKE & 6.66 & 0.12 & 11.50 \\
\hline TRR & 6.65 & 0.11 & 10.50 \\
\hline TRE & 6.18 & 0.13 & 14.50 \\
\hline TRS & 6.18 & 0.12 & 14.00 \\
\hline GME & 6.61 & 0.12 & 10.50 \\
\hline MTE & 6.54 & 0.05 & 11.50 \\
\hline NGR & 6.68 & 0.17 & 10.50 \\
\hline DLE & 6.61 & 0.17 & 11.50 \\
\hline
\end{tabular}

Derajat kemasaman $(\mathrm{pH})$ kopi hasil penelitian berkisar antara 6,18 sampai 7,19 . Besar kecilnya nilai $\mathrm{pH}$ dipengaruhi oleh proses penyangraian, semakin lama proses penyangraian, maka $\mathrm{pH}$ nya bisa semakin asam
(Purnamayanti, 2017). Proses fermentasi pada biji kopi juga ikut mempengaruhi nilai pH (Aditya, 2020), lokasi tumbuh, ketinggian dan proses budidaya serta pengolahan pasca panen juga mempengaruhi kadar $\mathrm{pH}$ pada biji kopi 
(Afandi, 2011; Butt, 2011; Ikrawan, 2012). Susunan genetik kopi, iklim atau cuaca juga mempengaruhi kualitas dan kandungan kimia kopi (Silva, 2005; Leroy, 2006).

Berdasar Tabel 3, diketahui bahwa nilai $\mathrm{pH}$ rata-rata kopi jenis Robusta sebesar 6,79 dan kopi jenis Exelsa sebesar 6,57. Terdapat dua sampel yaitu JBE dan RSR yang memiliki nilai $\mathrm{pH}$ lebih dari 7 , hal tersebut dimungkinkan karena tempat tumbuhnya pohon kopi, serta proses pengolahan yang kurang sempurna (Anggara, 2011).

Naiknya kandungan asam pada kopi dapat menyebabkan nilai $\mathrm{pH}$ turun (Yuliana, 2007; Desniar, 2012). Berdasar pada Tabel 3, Total Asam rata-rata total asam biji kopi jenis Robusta sebesar 0,15 $\%$ sedangkan jenis Exelsa $0,11 \%$. Menurut Anggara (2011), lokasi tumbuh kopi dan metode pengolahan (Reta, 2017) juga memiliki pengaruh terhadap kandungan asam pada biji kopi. Kadar asam kopi jenis Ribusta $10 \%$ dari total senyawa tiap biji kopi, sedangkan kopi jenis exelsa sebesar $4,7 \%$ tiap biji kopi (Anonymous, http://www.kopimat.com, 2020).

Nilai kadar air pada biji kopi harapannya rendah, karena akan berpengaruh pada dayan simpan atau umur simpan (Winarno, 1992; Pastiniasih, 2012). Besar kecilnya kadar air juga tergantung kepada jenis kopinya (Lilis, 2001) dan ketebalan biji (Boot, W, 2005). Berdasarkan pada Tabel 3, diketahui bahwa kadar air kopi jenis Robusta sebesar 10,63\% dan Exelsa sebesar $11,56 \%$. Rata-rata kadar air sampel kopi di bawah $12,5 \%$ sesuai ketentuan SNI 01-2907-2008. Kadar air di bawah $8 \%$ tidak disarankan bahkan cenderung di larang karena memerlukan biaya besar (Anonymous, 2020). Kadar air kopi jenis robusta lebih rendah daripada jenis exelsa yaitu 0.95 , nilai kadar air juga dipengaruhi oleh perbedaan ukuran kopi (Mulato, 2019). Kadar air kopi dengan kode TRE dan TRS lebih dari 14\%, hal tersebut dimungkinkan karena penyangraian yang kurang sempurna, disarankan untuk proses penyangraian pada atahap awal menggunakan suhu $165{ }^{0} \mathrm{C}$, setelah warna biji berubah menjadi hijau tua, maka suhu bisa dinaikkan hingga tahap penyangraian selesai (Anonymous, https://www.cctcid.com/, 2020). Tingginya kadar air pada kopi memiliki daya simpan yang kurang baik dan bahan kopi mudah diserang jamur serta mikroorganisme lainnya (Duniaji, 2020).

\section{KESIMPULAN}

\section{Kesimpulan}

Kopi dibudidayakan di 10 desa wilayah Kecamatan Gondang dan Jatorejo yang berada di Lereng Pegunungan Anjasmoro Kabupaten Mojokerto. Ketinggian lokasi penelitian antara 500 - 600 mdpl. Jenis kopi yang di budidayakan ada tiga jenis, yaitu Robusta, Exelsa dan Robusta stek dengan Exelsa. Berat/bobot buah kopi mengalami penyusustan setelah dijemur sebanyak 1.156,86 g (42,16\%). Ketika kulitnya dipecah, mengalami penyusutan berat sebesar 450,88 g (46,84\%). Penyangraian menggunakan oven berat turun rata-rata 215,04 g (45,79\%).

Diameter geometric jenis Robusta rata-rata lebih besar dari pada jenis exelsa, yaitu $13,80 \mathrm{~cm}^{3}$ dan $11,75 \mathrm{~cm}^{3}$. Sperisitas biji kopi jenis robusta rata-rata sebesar 218,94, sedangkan jenis Exelsa sebesar 192,48. Luas permukaan kopi jenis Robusta rata-rata sebesar $16,04 \mathrm{~cm}^{2}$ dan jenis Exelsa 12,85 $\mathrm{cm}^{2}$. Volume rata-rata kopi jenis Robusta $0,021 \mathrm{~cm}^{3}$ dan kopi jenis Exelsa $0,016 \mathrm{~cm}^{3}$. Derajat 
kemasaman $(\mathrm{pH})$ rata-rata kopi jenis Robusta sebesar 6,79 dan jenis Exelsa sebesar 6,57. Total Asam rata-rata total asam jenis Robusta sebesar 0,15\% sedangkan Exelsa 0,11\%. Kadar air kopi jenis Robusta sebesar 10,63\%, sedangkan kadar air kopi Exelsa sebesar $11,56 \%$.

\section{Saran}

Mutu kopi yang berkaitan dengan adanya biji pecah, serangga hidup, bau kapang menarik untuk dilakukan penelitian guna mengetahui kualitas biji kopi pengelolaan pascapanen yang dilakukan oleh petani.

\section{UCAPAN TERIMAKASIH}

Penulis mengucapkan terima kasih kepada LP4MP, Komunitas Sahabat Anjasmoro, petani kopi di Lereng Pegunungan Anjasmoro dan Ristekdikti yang telah membiayai penelitian ini melalui skema PDP.

\section{DAFTAR PUSTAKA}

Aditya, I. W. (2020, 10 25). Kajian Kandungan Kafein Kopi Bubuk, Nilai pH dan Karakteristik Aroma dan Rasa Seduhan Kopi Jantan (Pea Berry Coffee) dan Betina (Flat Beans Coffee) Jenis Arabika dan Robusta. Retrieved from https://ojs.unud.ac.id/index.php/ite pa/article/download/22653/14880/: https://ojs.unud.ac.id/index.php/ite pa/article/download/22653/14880/

Afandi, I. L. (2011). Studi Optimasi Dosis Ragi Kopi Luwak Multikultur Bermedia Tepung Maizena pada Pengolahan Kopi Robusta Secara Semi Basah. Skripsi. Jember: Jurusan Teknologi
Hasil Pertanian, Fakultas

Teknologi Pertanian,

Anggara, A. d. (2011). Kopi Si Hitam Menguntungkan: Budidaya dan Pemasaran. Yogyakarta: Cahaya Atma Pustaka.

Anonymous. (2020, Oktober 30). http://www.kopimat.com.

Retrieved from http://www.kopimat.com/2018/05/ perbandingan-kadar-kafein-dankeasaman.html

Anonymous. (2020, Oktober 25). http://www.thecoffeeguide.org/.

Retrieved from http://www.thecoffeeguide.org/cof fee-guide/coffee-quality/moisturecontent-and-drying/

Anonymous. (2020, Oktober 30). https://www.cctcid.com/.

Retrieved from https://www.cctcid.com/2018/10/2 5/penyangraian-biji-kopi/

AOAC. (2016). Official Methods of Analysis of the Association of Official Analytical Chemists. 18th Edition. Washington: AOAC International.

Balaya, M. B. (2013). Karakteristik Fisik dan Organoleptik Biji Kopi Arabika Hasil Pengolahan Semi Basah dengan Variasi Jenis Wadah dan Lama Fermentasi (Studi kasus di Desa Pedati dan Sukosawah Kabupaten Bondowoso). Agrointek, Vol. 7 (2).

Behailu, W. S. (2008). Coff ee processing and quality research in Ethiopia" in Coff ee Diversity and Knowledge, G. Adugna, B. Bellachew, T. Shimber,E. Taye, and T. Kufa, Eds. Ethiopia Institute of Agricultural Research (EIAR), Addis Ababa, Ethiopia, 307-316. 
Boot, W. (2005). Upping For Flavor vs Defects. USA: Broadway. Portland.

BSN. (2004). Kopi Bubuk. SNI 013542-2004. Jakarta: Badan Standardisasi Nasional.

Butt, M. S. (2011). Evaluating the effect of decaffeination on nutritional and antioxidant status of different coffee brands. Internet J Food Saf, Vol. 13. Hal: 198 - 207.

Desniar, R. I. (2012). Senyawa Antimikrobia yang Dihasilkan dari Mikroorganisme Bekasam. Jurnal Akuatik, Vol. 3 (2) Hal: 135-145.

Duniaji, A. S. (2020, Oktober 30). www.simdos.co. Retrieved from https://simdos.unud.ac.id/uploads/f ile_pendidikan_1_dir/bb6f2134c00 c8331d374d353d8c0e8b3.pdf

Fardiaz, S. (1992). Mikrobiologi Pangan. Jakarta: Gramedia Pustaka Utama.

Fisdiana, U. d. (2018, November 22 24). Pengaruh Lama Penyangraian Terhadap Kadar air, Rendeman, dan Warna Biji kopi Robusta (Coffea canephora var. robusta ex Frochner). Implementasi IPTEK dalam Mewujudkan Ketahanan Pangan Nasional, pp. 1 - 6.

Giomo, G. S. (2012, November ). Evaluation of green bean physical characteristics and beverage quality of Arabica coff ee varieties in Brazil. Proceedings of the 24th International Conference on Coff ee Science San Jos'e (Costa Rica) San Jos'e, CA, USA, .

Ikrawan, Y. H. (2012). Kajian Konsentrasi Koji Saccharomyces cerevisiae varr. Ellipsoideus dan Suhu Pada Proses Fermentasi Kering Terhadap Karakteristik Kopi. Skripsi. Tidak Diperjualbelikan Secara Umum, Skripsi. Universitas Pasundan. Bandung.
Jain, R. K. (1997). Physical properties of Pearl millet. Jounal Agricultural Engineering Res, Vol. Hal. 85 - 91.

Kismurtono, M. (2012). Fed-batch alcoholic fermentation of palm juice (Arenga pinnata Merr): Influence of the feeding rate on yeast, yield and productivity. International Journal of Engineering and Technology, Vol. 2 (5), Hal: 795 - 799.

Leroy, T. F. (2006). Genetics of coff ee quality. Brazilian Journal of Plant Physiology, Vol. 18 (1) Hal. 229 242.

Lia, F. d. (2017). Sistem Produksi Agroindustri Kopi Arabika (Studi Kasus PT. Sinar Mayang Lestari Kecamatan Pengalengan Kabupaten Bandung). AGRISEP, Vol. 16 (2) Hal: 123 - 132.

Lilis. (2001). Kasus Fisika Pangan Dua Jenis Kopi (Coffea sp) yang Diukur Beberapa Sifat Fisiknya. . Bogor: Institut Pertanian Bogor.

McCabe, W. J. (1986). Unit Operation of Chemical Engineering. New York: McGraw-Hill.

Mohsenin, N. N. (1978). Physical Properties of Plant and Animal Materials. New York: Gordon and Breach Sci. Publ.

Mulato, S. (2019, Juli 22). www.cctcid.com. Retrieved from https://www.cctcid.com/2019/07/2 2/perubahan-fisis-dan-kimiawibiji-kopi-selama-penyangraian/: https://www.cctcid.com/2019/07/2 2/perubahan-fisis-dan-kimiawibiji-kopi-selama-penyangraian/

Muschler, R. (2001). Shade improves coffee quality in a sub-optimal coff ee-zone of Costa Rica. Agroforestry Systems, Vol. 85 Hal: 131 - 139.

Pastiniasih, I. (2012). Pengolahan Kopi Instan Berbahan Baku Kopi Lokal 
Buleleng, Bali (Campuran Robusta Dan Arabika). Bogor: Fakultas Teknologi Pertanian. Fakultas Teknik. skripsi.

Purnamayanti, N. P. (2017). Pengaruh Suhu dan Lama Penyangraian terhadap Karakteristik Fisik dan Mutu Sensori Kopi Arabika (Coffea arabica L). Jurnal Beta (Biosistem dan Teknik Pertanian), Vol. 5 (2). Hal: 39 - 48.

Reta, R. M. (2017). Reducing the acidity of Arabica coffee beans by ohmic fermentation technology. . Food Research, Vol 1 (5) Hal: 157 - 160.

Silva, E. A. (2005). The influence of water management and environmental conditions on the chemical composition and beverage quality of coffee beans. Brazilian Journal of Plant Physiology, Vol. 17 (2) Hal. 229 238.

Singh, J. a. (2015). Fabrication of Hybrid Solar Dryer. International Journal of Scientific and Research Publications, Vol. 5 (6). Hal: 1 - 8.

Strip, G. (2013). Medical Instruments. . Korea: All medicus Co., Ltd.
Sucanti, N. L. (2015). Keragaan Usaha Pengolahan Kopi Sedap Enak Rasanya (SER) pada UUP Mekar Sari, Banjar Jempanang, Desa Belok Sidan, Kecamatan Petang, Kabupaten Badung. Kecamatan Petang, Kabupaten Badung, Vol. 4 (1) Hal. 19 - 28.

Widyotomo, S. d. ( 2015). Penentuan Karakteristik Pengeringan Kopi Robusta Lapis Tebal. Instiper, Vol. 12 (1). Hal: 15 - 37.

Winarno, F. G. (1992). imia Pangan dan Gizi. Jakarta: PT Gramedia Pustaka Utama. .

www.weather.com. (2020, Agustus 31). https://weather.com. Retrieved from https://weather.com: https://weather.com/weather/mont hly/1/46f869b3a19105d1c3b74eb0 2425af44df2ee18bb240e5da5b52d f5f6788b05f

Yuliana, N. (2007). Profil Fermentasi Rusip yang Dibuat dari Ikan Teri (Stolephorus sp). Agritech, Vol. 27 (1) Hal: 12 - 17. 